\title{
Parvo Virus Induced Red Cell Aplasia In An HIV Infected Child
}

\author{
S Daga, N Tayade
}

\section{Citation}

S Daga, N Tayade. Parvo Virus Induced Red Cell Aplasia In An HIV Infected Child. The Internet Journal of Infectious Diseases. 2005 Volume 5 Number 2.

DOI: $\underline{10.5580 / 882}$

\section{Abstract}

We describe a case of young boy with HIV infection complicated by parvovirus presenting to us with severe anemia and failure.

\section{INTRODUCTION}

The association between parvovirus infection and transient aplstic crisis is well known. In immunocompromised and patients with hemolytic anemia it causes chronic bone marrow suppression with predominantly affecting red cell line.

\section{CASE REPORT}

Nine year old boy, a diagnosed case of HIV infection, was third time admitted for pallor. The child was receiving triple drug anti- retro viral therapy, a combination of stavudine, lamivudine, nevirapine with cotrimoxazole prophylaxis. On examination, the child had severe pallor, tachycardia and tachypnea.

He had hepatomegly,liver four centimeters below the costal margin, spleen was not palpable.Investigations revealed: HB-2 g/ dl,hematocrit-3.9\%, RBC count- 0.45 million per microlitre, reticulocyte count $-<0.1 \%$, normocytic, normochromic, RBC morphology. Total leucocyte count 10,100/dl with P- 78\%, L- 18\%, E- 2\% and M- 2\%. CD4 count was 75/ cubic millimeters, CD4: CD8 ratio was 0.11 . Platelet count was 5,24000/dl. During previous two admissions hemoglobin was $1.9 \& 1.8, \mathrm{RBC}$ count was 0.77 million per microlitre and 0.67 million per microlitre respectively. Platelet and leucocyte count were normal.

In view of persistent depletion of red cell line, a possibility of red cell aplasia was kept in mind. Bone marrow aspiration revealed marked erythroid hypoplasia with many giant erythroblast with dispersed chromatin highly suggestive of associated viral infection. Hence, DNA PCR for parvovirus was done and it turned out to be positive.

\section{Figure 1}

Figure 1: Bone marrow showing giant erthroblast, The cytopathic effect of B19 parvovirus infection of the erythroid progenitor cell and eryythoid hypoplasia:Leishman stained

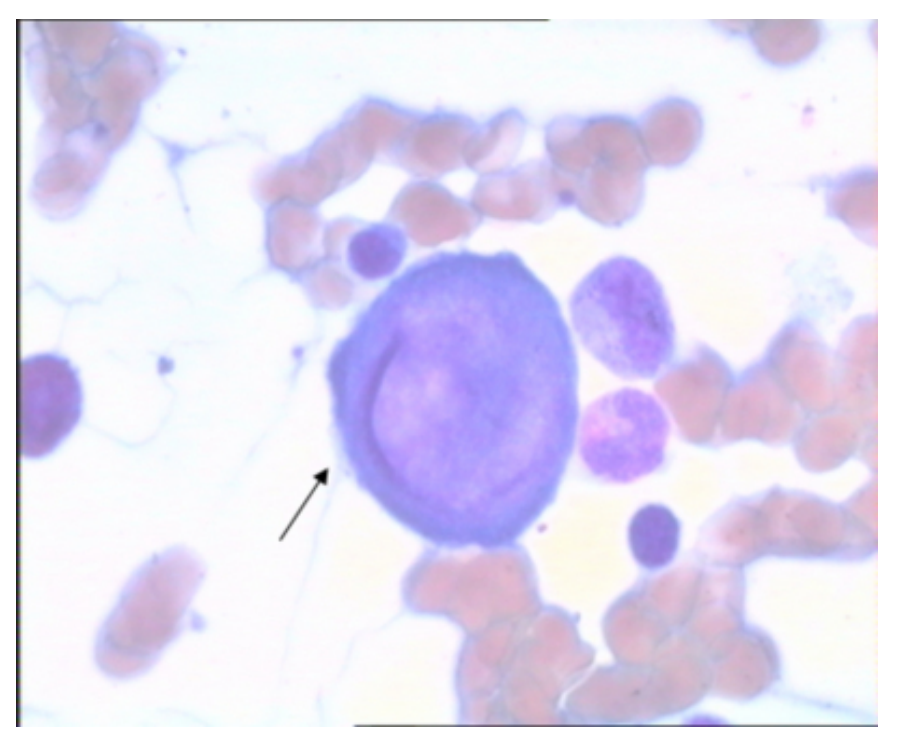

\section{DISCUSSION}

Anemia in patients with HIV is multifactorial. The most common causes include nutritional deficiencies; iron, folic acid, and less commonly, Vitamin B 12, immunohemolysis, hemorrhage \& drug toxicities. Bone marrow suppression caused by HIV virus itself, other infectious agents, or malignancy also cause anemia ${ }_{1}$ ).persistent anemia with reticulocytopenia made us suspect aplastic anaemia. Parvovirus B19 infection is known to cause aplastic anemia with a low or absent reticulocyte count. Bone marrow aspiration revealed giant erythroblasts with dispersed chromatin, the markers of parvovirus infection ( 
fig. 1 ). DNA PCR confirmed the diagnosis.

Parvovirus B19 is a small single stranded DNA virus belonging to genus erythrovirus. This infection should be suspected in presence of severe normocytic, normochromic anemia, decrease retoculocyte count and CD4 count less than 100 cells $\left(_{2}\right)$. HAART itself may eradicate pathogens (3). Standard treatment for persistent parvovirus B 19 and immuno suppression is IVIG $400 \mathrm{mg} / \mathrm{kg}$ per day for five days $\left.{ }_{4}\right)$. In our case HAART therapy was not able to prevent chronic anemia, however IVIG administration was not possible due to economical constraints.

\section{ACKNOWLEDGEMENTS}

We would like to thank Dr. S.R. Rane for her expert opinion on bone marrow examination.

\section{CONTRIBUTIONS}

SRD managed the case, finalized the draft and would stand as guarantor.NBT reviewed the literature and prepared the manuscript.

\section{CORRESPONDENCE TO}

Dr. N. B. Tayade, Senior Resident Department Of Pediatrics, B.J.M.C., Pune-411001. Email : nt_2005@rediffmail.com

\section{References}

1. Laufer Scott G. Medical Management of HIV disease in Children - PediactrClin N Am 2000 vol47 no 1; 134 2. Bartlett J B, Gallant J E 2004 Medical Management of HIV infection;pPublieshed by johns Hopkins Medicine Health Publishing Business Group,Baltimore,MD 21231;2004:381.

3. Ware A J, Moore T, Resolution of Chronic parvovirus B19 induced anemia by use of HAART, in patient with AIDS; Clin Infect Dis 2001; 32: E 122.

4. Frickhofen N, Abkowitz J L, Safford M, Berry M, Antunez-de-mayolo, Astrow A, Cohen R, Halperin ira Lambert, Mintzer D, Cohen B, Young N, Ann Intern Med 1990;113: 926.

5. Abkowitz J L, Brown K E, Wood R W, Kovach N L, Green S W, Clinical relevance of parvovirus B 19 as a cause of Anemia in patient with HIV infection.J Infect Dis 1997; 176:269. 


\section{Author Information}

S. R. Daga

Department of Pediatrics, B.J.M.C.

N. B. Tayade

Department of Pediatrics, B.J.M.C. 